\title{
African Unfreedom: An Escapist Excuse for Underdevelopment
}

\author{
John Ezenwankwor ${ }^{1}$, Wenceslaus Madu² \\ ${ }^{1}$ Directorate of General Studies, Federal University of Technology, Owerri, Nigeria \\ ${ }^{2}$ Imo State Polytechnic Umuagwo, Owerri, Nigeria \\ Email: johnsmart400@yahoo.com,frmadu2000@aol.com
}

How to cite this paper: Ezenwankwor, J., \& Madu, W. (2020). African Unfreedom: An Escapist Excuse for Underdevelopment. Open Journal of Philosophy, 10, 460-468. https://doi.org/10.4236/ojpp.2020.104032

Received: August 25, 2020

Accepted: November 7, 2020

Published: November 10, 2020

Copyright (c) 2020 by author(s) and Scientific Research Publishing Inc. This work is licensed under the Creative Commons Attribution International License (CC BY 4.0).

http://creativecommons.org/licenses/by/4.0/

\begin{abstract}
The African continent has played host to various colonizers from the western world. Most of the countries have negative tales of the activities of the colonizers before independence as well as their neo-colonizing activities after independence. On this basis, it is common for most African scholars to impute the guilt of African woes, particularly underdevelopment, to the activities of the colonizers. They consider the whole gamut of colonial legacies in Africa as a doom and a problem to the African continent. Some of the scholars compared the relationship between the Africans and their colonizers in terms of father-son relationship where a father, rather than give the son fish, gives him poison. This paper, employing a descriptive method of research accepts the fact that the colonizers were involved and are still involved in some activities that are detrimental to African development but rejects the position that the colonizers are entirely the problem. Its main aim is to stress the point that the greater militating factors against the proper development of the African continent are self inflicted. It gives a verdict that Africans as human beings like the colonizers, have the freedom to take control of their events and take the responsibility for their actions that have in various ways affected her development instead of imputing blame to others.
\end{abstract}

\section{Keywords}

Africa, Colonizers, Freedom, Unfreedom, Responsibility, Underdevelopment

\section{Introduction}

The dominance of the feelings of hatred and disdain among African scholars for the colonizers is to be properly understood in terms of the descriptions given to the colonizing activities by various scholars particularly within the African continent. The colonizers or the "white men", as they are often colloquially called, 
are seen as those who have come to "dominate", "subdue", "exploit" and "enslave" the African. The recognition of this fact, according to most scholars, was what prompted a rousing hatred for all colonial activities by the African. Edgar \& Msumza Ka (1996: p. 59) for example, writes that the activities of the colonizers are great barriers that makes it difficult for the Africans to become full and free citizens in their own land. This is considered unacceptable. The African therefore needed to use whatever is within his arsenal to fight this enslavement and become free. Whether this has been achieved today particularly in independent African states is debatably unclear as questions of neo-colonialism remain daunting tasks for the African.

This paper accepts the general argument of most African scholars that there are some ulterior motives to the liberal commitment of the former colonizers to their African colonies than is suggested by the grant of political independence (Beidelman, 2012: p. 5). It is therefore very sympathetic to the African for the "sorry tales" of colonialism and neo-colonialism but denounces the general African attitude towards freedom. She can no longer "sit down" and blame the colonizers but should take the responsibility for her present and future destiny. Similarly, we recognize that the allegation of subjugation or enslavement of the "black" by the "white" is an undeniable injustice (Anaele, 2014). However, we firmly assert the African failure to fully utilize his potentials as a member of the homo sapiens with an injunction in Genesis 1: 28, to conquer and subdue the world. The "white men" or the western colonizers have faithfully risen up to claim this right but went beyond the boundaries of that injunction to become unjust to fellow humans. The "black men" or the Africans are yet to match up with the full requirements of this injunction. This is considered as the reason for his present woes and not the actions of the colonizers. The presentation of the problem of this work which is centered on the claim that colonizing activities underdeveloped Africa is here divided into three parts. The first part deals with the explanation of the basic terms, the second with the review of the African sentiments on colonialism and finally the third part is an evaluation of the real African situation and a proposal for the way towards a responsible African ownership of her situation.

\section{African Unfreedom}

References to the word freedom are made when persons are not constrained externally or restrained internally. In most cases, freedom is used interchangeably or as a synonym for the word liberty. However, proper recourse to their origins shows slight differences between the two words. Originally, liberty meant the separation of one or group of persons from the endangered or enslaved group and made such persons independent while freedom implied some kind of belonging to a community or group of free men. Freedom is a kind of claim right that grants one the power of choice in his/her actions. The average African scholar believes that there is a constant interference from the western society in her affairs and therefore constraining her freedom of choice (Scott, 2012). The 
view that African states are free is taken by some African scholars as lip serving and unreal. They therefore see the African as entirely un-free, not because of some internal restraints but because they are constrained by events that are not within their control. They are constrained as a result of some set colonial schemes that make it impossible to make proper choices towards proper development and self wellbeing.

The scholars in this camp define un-freedom as situations where people lack the capacity to make choice, the capacity to act or even decide what to do; the situations where one's economic, psychological, cultural and political choices are dependent on the decisions of others (Dukor, 2012: 50). Among the list of issues that make it impossible for her to properly organize and take control of her life are a number of things which come from outside the continent. It is believed and strongly held among most African scholars that the colonizers implanted a lot of constraining forces such as capitalism and imperialism (Campbell, 2015) within the African soil. These forces, they argue, make it practically impossible for the African to independently progress with self development.

It is our position that this kind of definition of the African problem is highly deficient for its neglect of the aspect of internal restraint. As a matter of fact, internal restraints in most challenging situations are more debilitating towards progress than external restraints. This is the problem of the African in her quest for development. Rather than focus on these internal forces, most of these scholars impute the entire blame of the African problems on the lack of freedom endangered from external forces. There are barrages of restraining forces emanating from within the African continent, which alone, have helped to under-develop Africa. In spite of internal restraining forces, most Africans continue to bemoan their problems as traps set by the colonial masters. We consider a few of such sentiments below.

\section{Anti Colonial Sentiments in Africa}

The native hate for the colonial masters and their work in the African continent is quite understandable when one considers the inhuman conditions the colonizers placed the Africans during their colonizing activities. These were carefully documented and pointed out by most African scholars who are generally in agreement that most colonizers considered the Africans unfit to be granted freedom to manage their affairs or make desired choices (Ezenwankwor, 2012). This kind of feeling among most African scholars birthed the various movements for African freedom which was championed by some prominent African leaders. Such leaders considered the colonial masters' activities as an unbridled subjugation of the African people and her affairs to the selfish desires of the colonizing west who merely considered Africa as an object of interest (Wesseling, 1996: p. 3). African peoples were therefore seen as people who were unfit to be granted freedom to make own choices. In order to show that they were right in their perception of Africa, they descended on the African soil like some kind of "big brothers" and consigned every native value as primitive and antiquated. Dukor 
(2012: 68) recounts for example, that in replacement for what they considered archaic and crude in African soil, they dropped for the African, crises, wars, devaluation and negation of values as a legacy in the form of European religion and education. To further punish the African, these misplaced values were presented in the mentality, language and conception of the European. Dukor's position was not as biting as Pennycook (1998: p. 24) who never spared his feelings about the colonizing activities in the African soil. According to him, they came to Africa with a deceptive garb for modernization when in reality they were in a mission to halt its natural progress through the strategy of exclusion of locals from decisions that affected and controlled their lives.

In a passionate telegram to Tshombe of Katanga, who in a twist (from apparent deception from imperialists) contended that the native Government of Congo was illegal and Communist-dominated, Kwame Nkrumah of Ghana wrote to him denouncing his position and accusing him of being a puppet of Belgian officials who are opposed to African freedom in all its ramifications. Writing to him, he reminded him that in line with many other African leaders in the past, the colonizers will also use and dump him as soon as he has served their purpose. As a warning therefore, he informed him that, as long as he plays puppet to the Belgian authorities, no true African will have confidence in him but will eternally be linked with the exploiters and oppressors of the continent particularly the exploiters of your native country. He finally appealed to him to denounce the exploiters for his own good (Nkrumah, 1961: p. 250). Nkrumah made it clear that the colonizers are simply exploiters and oppressors with no positive intention for the colonized. With the struggle for independence therefore, African nationalists like Nkrumah, struggled to get rid of what they considered as the exploiters of African heritage and values. In its stead, they tried to choose African leaders who will restore and protect African values.

Post independent Africa: Taking over from the colonizers was not as easy as expected and far beyond the takeover; the new values created by the colonizers became landmines for the African peoples and her leaders. Soon they realized that even though they have taken over the governance of their countries, they were yet to be free. The landmines include the European legacies of education and religion veiled in European languages and cultures. The African had to contend with a conscience battle between the two values-African and Western at the same time. This difficulty resulted to the search for ideological positions suitable to the African in order to move on with her new found liberty and freedom mingled with a serious sympathy among the Africans for new religions and cultures of the colonizers. Among the suggested ideologies was Nkrumah's consciencism. His theory of consciencism is expected to be an intellectual map where an opportunity is created for the African to properly digest the positive western, Islamic and Euro-Christian values towards an adoption of what will be truly African or what he terms "African personality" (Nkrumah, 1970: pp. 56-70). These ideologies helped more or less in bringing a kind of African consciousness in the general attitude of the natives particularly in their encounter with new 
values but did not help much in bringing a proper development required in a new emancipating continent. In the bid to move on with the required development strategies, some other challenges referred to as neo-colonial issues emerged. As clearly pointed out by Dukor (2010), Africans were considered not capable for liberty and as well unfit to handle their affairs. To prove this, a lot of things set in motion and left for the Africans by the colonizers where done in such ways that the African cannot handle them without recourse to the colonizers. Dukor (2010) as a matter of fact, feels that every legacy of the colonial masters in Africa is targeted to African doom. He calls such legacies as misnomers from parents to their children-colonizers to the colonized.

Unarguably, as I indicated earlier (Ezenwankwor, 2012), the deceptions of the colonizers as truly pointed out by most African nationalists, have some devastating impact on the African values to the extent that today she is confused on how to advance economically or even develop her political and moral architecture. It is also undeniably true that the colonizers came to Africa with some ulterior and selfish economic motives. This is evidently clear in their selfish defense of the unjust seizure and exploitation of the natural resources of all colonized territories (Meredith, 2005: pp. 95-97). The colonial policy aimed at assimilating the native African into the colonizer's social life patterns was also a notable selfish program of the colonizers aimed towards total annihilation of the African peoples (Alemazung, 2010). The list is endless to what the African can point to as the negative impact of the colonial activities on her freedom to make choices. Truly, these have great influence on her developmental strides. To what extent can we hold that these problems are the sole reasons for the African underdevelopment?

\section{Colonialism and African Underdevelopment}

The fact that colonialism played a major role in the poor development of African is unquestionable. The colonial method and legacies in Africa, as well as the way they continued to interfere in African affairs in the form of neocolonialism make it axiomatic that they are culpable for African underdevelopment. This position however should not exonerate the African or make him/her less culpable about African underdevelopment as we often find in the writings of most African scholars. For example in most of their works, the usual words used for referencing the west in their colonizing mission were exploiters, and oppressors (Nkrumah, 1961: p. 250) and they allude to them as those who have come to enslave or subdue the African.

A kindergarten story several years ago, of the biblical Esau and Jacob (Gen. 25-33), left some pupils angry with Isaac. Some were even angry with God who allowed Jacob to receive the blessings meant for Esau. As children, we may have seriously considered Jacob to be a wicked and irresponsible brother to Esau. However, as adults and armed with further reflections on the story, we are bound to extend further blame to Esau as an irresponsible person for giving up her 
birthright for a mere "stew". If we grant the status of a baby to the traditional African when the Colonizers were solely in charge, will he continue to remain a child even in the $21^{\text {st }}$ century, several years after independence? He must move beyond the place the colonizers left him as described by Dukor (2010) to a mature parent African.

African culpability: The scriptural and philosophical considerations of man, place him far higher than other creatures. For example, in the book of Genesis (1:26), man is considered as a creature distinct from others because he is made in the image of God. Beyond that, he is, as well, given the authority to subdue other created beings. This passage is very important in our consideration of the culpability and non culpability of the African in her underdevelopment because of the subjugatory powers granted to man (the African included) over all other creatures. Philosophy, as well, gives man special place among other creatures and defines him as a rational being. As a result of such special or privileged position of man, more is expected from him in his actions. Therefore, even if we excuse a child for blaming Jacob as we find in the biblical story, the same excuse will not be granted to a man with the ability to subjugate, conquer and reason.

Who should take the blame for the African underdevelopment? Should we blame the colonial masters or should the Africans take the blame? These questions may not be properly answered without due consideration to the periods and stages of the underdevelopment. Placed in a balancing scale for example, the equilibration of the blame between the early and middle part of the $20^{\text {th }}$ century may be counted at the rate of $70-30$; seventy for the colonizers and 30 for the Africans. On the other hand, between the late $20^{\text {th }}$ century and early $21^{\text {st }}$ century, the blame shifts to the ratio of $30-70$; thirty for the colonizers and seventy for the Africans. This shows a downward movement for the cause of underdevelopment through the years, resulting from the activities of the colonizers and an upward movement for underdevelopment, resulting from the activities of the Africans themselves. The trend gives no credit to the African who constantly consider himself as the bereaved. It is therefore clear that most African scholars have merely disregarded the real African problems as a result of their obsession of the colonial impact in Africa. Unless this attitude is changed, Africa may never truly be on the way to progress. The ratings above simply indicate the opportunity costs for both the African and the Colonizers to maximally utilize the biblical kabash and the philosophical Ens rationis. The African failed woefully in the opportunity he had and rather than improve his lot by proper use of reason and if necessary, subjugate "others" under him, he became the architect of his own woes. The colonizer as ens rationis was wiser and like biblical Jacob took the biblical injunction to kabash, as a tool in her 'exploitation of the African continent for his own ends. The African, particularly the $21^{\text {st }}$ century African, has no excuse. He should blame no one but himself.

\section{Internal Constraints for African Development}

The $21^{\text {st }}$ century is not a century to blame the colonizers for African woes be- 
cause her woes are the resultant effects of her laziness, stupidity and tepidity. This is the century when Africans as ens rationis with the injunction to kabash should, like the colonizers, take control of their events and take the responsibility for their actions instead of imputing blame to others. No excuses! One religious expatriate who worked in Nigeria for ten years went home and gave a description of Nigerians as very happy people. Explaining further, he indicated that they clap, sing and pray happily, sitting twenty in a bus meant for eleven people on a journey of six hours. They are ever happy to welcome electricity lights from the national grid with shouts of ovation after two days to one week of blackout. They are happy to see water running through the city taps once in a while. They never question nor grumble when these amenities are not there. Great compliment!

The level of laxity and tepidity in the continent is unparalleled. No one seems to care about the general wellbeing of the continent yet everyone practically cares about his/her personal affair. This is where most continents of Africa have gotten it wrong. What our expatriate religious gentleman failed to report is that sometimes, you find among the commuters who sit clapping in the rickety and overloaded buses, those who have within the course of one year evaded tax payments that can be used to purchase four good commuter buses for the improvement of mass transit system. Tax evasion considered a very serious crime in most western countries is comparable to mere offense in most African countries and considered less serious than collection a bribe (Ross \& McGee, 2012). Most countries of the world survive through the tax payers' money. A country where only civil servants pay tax is, as well as dead. Most African countries belong to this group. The colonizers did not teach Africans to evade tax! They rather encouraged its payment. Why should they be blamed for underdevelopment which is a resultant effect of tax evasion?

Most companies and projects handed over to the Africans by the colonial masters on their exit from the continent may have suffered some setbacks because of their reluctance to disclose some basic knowledge to Africans in such firms but more harm came to such firms because of the laxity, laziness of African new owners and workers. Today, it is impossible to see any government agency in Africa that generates money in spite of the numerous investments in them monthly.

Labour unionism which is everywhere in the world and used to checkmate corrupt government and exploitative employers is now a snare in most parts of Africa, particularly Nigeria. Labour unions, originally the colonial legacy which helped to organize workers of different cultural and religious backgrounds towards promotion of labour and its fruits (Ingleson, 2001) has now turned to a monster. Workers today who do not work expect to receipt payments for what they did not work for and when they are denied such payments, the labour unions will rise to their defence! At the end, what result is expected? Underdevelopment!

The name for the problem of African underdevelopment is corruption! The 
way forward to proper development is to stop corruption! The war against corruption must go beyond the pages of newspapers, political blueprints and church homilies to real commitment in the farms, factories and the work places!

\section{Concluding Remarks and Recommendations}

It is generally sickening to see Africans in the $21^{\text {st }}$ century continuously crying woe for their underdevelopment while blaming the colonizers. Arguably, we can assert that what the colonizers did is in line with her nature as "man" with a high reasoning sense and with a command to subdue the earth. The determination of the boundaries of justice which may be the next problem in his bid to kabash the African territories, go beyond the boundaries of this paper to the moral or legal philosopher. That the African is unable to properly develop her environment today is the resultant effect of her failure and not because he has been unfree following the activities of the colonial masters. Like China and other Asian nations who went through colonial rule as well, Africa should rise up to face her problems and be honest with the pursuit of their desired goals without fear. She should at this point decide to own up her affairs and take her destiny into her hands and take a leap. That leap will involve the immolation of selfish interests to national interests.

We therefore recommend that for Africa to be on the proper part to development, the drive for excellence should become the agenda for her nations. In addition, there should be a total mental extinction of the colonial and neo colonial phobia which keeps portraying Africa as unfree. She must be determined to take total responsibility for her affairs including her joys and sorrows. She must be ready to renounce all forms of corruption particularly laxity at work places, tax evasion and pen robbery. As a form of policy, African nations should consider total privatization of major government agencies for profitability. The will to do the above will be strengthened by the support of a determined government that will be ready not just to make laws but to put proper machinery for its implementation.

\section{Conflicts of Interest}

The authors declare no conflicts of interest regarding the publication of this paper.

\section{References}

Alemazung, J. A. (2010). Post-Colonial Colonialism: An Analysis of International Factors and Actors Marring African Socio-Economic and Political Development. Journal of Pan African Studies, 3, 62-84.

Anaele, C. (2014). Slave-Trade, Christianity and European Imperialism in Nigeria: A study of the Ante and Post Abolition Periods. Canadian Social Science, 10, 78-82.

Beidelman, T. O. (2012). The Culture of Colonialism: The Cultural Subjection of Ukagu$r u$. Bloomington, IN: Indiana University Press.

Campbell, H. (2015). Imperialism and Anti-Imperialism in Africa. Monthly Review, 67, 
98. https://doi.org/10.14452/MR-067-03-2015-07 7

https://www.questia.com/read/1P3-3744632451/imperialism-and-anti-imperialism-inafrica

Dukor, M. (2010). The African Freedom, the Freedom of Philosophy. Sarbrucken: Lambert Academic Publishing.

Edgar, R. R., \& Msumza Ka, L. (1996). Freedom in Our Lifetime: The Collected Writings of Anton Muziwakhe Lembede. Athens: University of Ohio Press.

Ezenwankwor, J. (2012). Dukor's African Unfreedom and Moral Responsibility. Open Journal of Philosophy, 3, 213-217. https://doi.org/10.4236/ojpp.2013.31A035

Ingleson, J. (2001). The Legacy of Colonial Labour Unions in Indonesia. The Australian Journal of Politics, 47, 85-100. https://doi.org/10.1111/1467-8497.00220

Meredith, M. (2005). The State of Africa: A History of Fifty Years of Independence. London/New York: Free Press.

Nkrumah, K. (1961). I Speak of Freedom: A Statement of African Ideology. New York: Praeger.

Nkrumah, K. (1970). Consciencism: Philosophy and Ideology for Decolonization. New York: Monthly Review Press.

Pennycook, A. (1998). English and the Discourses of Colonialism. London: Routledge.

Ross, A. M., \& McGee, R. W. (2012). Attitudes toward Tax Evasion: A Demographic Study of South African Attitudes on Tax Evasion. Journal of Economics and Economic Education Research, 13, 13-58. https://doi.org/10.2202/2154-4611.1028

Scott, B. (2012). African Union Summit: Disunity on Display. The Christian Service Monitor.

https://www.questia.com/read/1P2-32559045/african-union-summit-disunity-on-display

Wesseling, H. L. (1996). Divide and Rule: The Partition of Africa, 1880-1914 (Trans. J. Pomerans). Westport, CT: Praeger. 